\title{
Effects of nitrogen addition on plant-soil-microbe stoichio- metry characteristics of different functional group species in Bothriochloa ischemum community
}

\author{
ZiWen Zhao ${ }^{1}$, YanLi Qin ${ }^{1,3}$, Yang Wu ${ }^{1}$, WenJing Chen ${ }^{1}$, Sha Xue ${ }^{1,2, *}$, GuoBin Liu ${ }^{1,2}$ \\ 1 State Key Laboratory of Soil Erosion and Dryland Farming on the Loess Plateau, Institute of Soil and Water Conservation, \\ Northwest A\&F University, Yangling 712100, China \\ 2 Institute of Soil and Water Conservation, Chinese Academy of Sciences and Ministry of Water Resources, Yangling 712100, China \\ 3 Key Laboratory of National Forestry and Grassland Administration on Ecological Hydrology and Disaster Prevention in Arid Regions, \\ Xi'an University of Technology, Xi'an 710048, China
}

\section{H I G H L I G H T S}

- Both plants and microbes were strictly homeostatic.

- Companion species were more susceptible to $\mathrm{P}$ limitation than dominant species.

- Added $\mathrm{N}$ aggravated stoichiometric niche overlap among species.

- Compositae had a greater effect on soil microbes than Gramineae in the rhizosphere. - Effects of $\mathrm{N}$ addition on species were different across functional groups.

\section{ARTICLE INFO}

Article history:

Received April 19, 2021

Revised June 8, 2021

Accepted June 15, 2021

\section{Keywords:}

$\mathrm{N}$ addition

Ecological stoichiometry

Stoichiometric homeostasis

Nutrient limitation

Stoichiometric niche

Plant-soil-microbe system
GRAPHICAL ABSTRACT

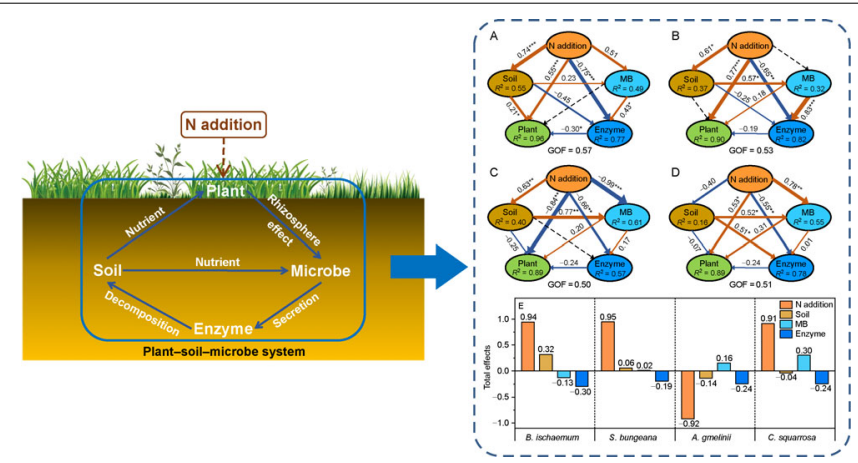

A B S T R A C T

Nitrogen $(\mathrm{N})$ deposition, the source of $\mathrm{N}$ input into terrestrial ecosystems, is exhibiting an increasingly serious impact on the biogeochemical cycle and functional stability of ecosystems. Grasslands are an important component of terrestrial ecosystems and play a key role in maintaining terrestrial ecosystem balance. Therefore, it is critical to understand the effects of nitrogen addition on grassland ecosystems. We conducted gradient $\mathrm{N}$ addition experiments $\left(0,3,6\right.$, and $\left.9 \mathrm{~g} \mathrm{~N} \mathrm{~m}^{-2} \mathrm{y}^{-1}\right)$ for three years in grassland communities with similar site conditions. We utilized four typical herbaceous plants, including the dominant species Bothriochloa ischemum (B. ischemum) and companion species Stipa bungeana ( $S$. bungeana), Artemisia gmelinii (A. gmelinii), and Cleistogenes squarrosa (C. squarrosa), to explore how different plant-soil-microbe systems respond to $\mathrm{N}$ addition. Stoichiometric homeostasis analysis demonstrated that both plants and microbes were strictly homeostatic. However, the companion species were found to be more susceptible to $\mathrm{P}$ dominant species. Furthermore, aggravated overlap in stoichiometric niches between plant species were observed at the N6 and N9 levels. Vector analysis indicated that the vector angle was $>45^{\circ}$ regardless of plant species and $\mathrm{N}$ levels, suggesting that there was a strong $\mathrm{P}$ limitation in the rhizosphere microbial community. Variation partitioning analysis revealed that the Composite roots exhibited a greater effect (explaining $34.7 \%$ of the variation) on the rhizosphere microbes than on the Gramineae, indicating that there may be more intense nutrient competition in its rhizosphere. In general, the effects of $\mathrm{N}$ addition on species were different across functional groups, with a significant positive effect on the Gramineae ( $B$. ischemum, S. bungeana, and $C$. squarrosa) and a significant negative effect on the Compositae (A. gmelinii), which should be fully considered in the future ecological management and restoration.

(c) Higher Education Press 2021

\footnotetext{
* Corresponding author

E-mail address: xuesha100@163.com (S. Xue)
} 


\section{Introduction}

Nitrogen $(\mathrm{N})$, the primary protein component in plant tissues and a component of important metabolic organic compounds such as nucleic acid and chlorophyll in plant cells, is an essential element for plant growth and development (Moreau et al., 2019). Additionally, $\mathrm{N}$ is also an important nutrient element on which the growth and activity of soil microbes depend (Hill et al., 2014). Although $\mathrm{N}$ is abundant in the atmosphere, most of it exists in an inert form $\left(\mathrm{N}_{2}\right)$ that cannot be directly absorbed and utilized by plants and microbes, resulting in $\mathrm{N}$ being one of the most common limiting nutrients in terrestrial ecosystems (LeBauer and Treseder, 2008; Moreau et al., 2019). Research has demonstrated that an appropriate amount of $\mathrm{N}$ addition exerts positive effects on the plant-soil-microbe system, such as increasing plant biomass (Wang et al., 2010), $\mathrm{N}$ content in plant tissues, soils, and microbes (Wei et al., 2013; Wang et al., 2018; Zhang et al., 2019), and system nutrient cycling (Marklein and Houlton, 2012). However, excessive $N$ input increases the risk of soil acidification and nutrient leaching, causing a series of ecological problems, such as reduced productivity, species diversity loss, and ecosystem degradation (Wei et al., 2013). The responses of functional groups to environmental changes often vary due to their different functional traits and species characteristics (Mao et al., 2017). Studies have illustrated that $\mathrm{N}$ addition exerts opposite effects on the underground biomass of gramineous herbs and forbs (Song et al., 2012). At present, there is no consensus on the effects of $\mathrm{N}$ enrichment on plant communities or the potential mechanisms of these effects (Chen et al., 2016a). Therefore, plant-soilmicrobe system responses to $\mathrm{N}$ addition, such as changes in plant functional traits, soil physicochemical properties, soil microbial activity, and the interactions among them under $\mathrm{N}$ application background, is a scientific issue that deserves extensive attention from researchers (Marklein and Houlton, 2012; Wang et al., 2018).

Ecological stoichiometry is an emerging field that combines the basic principles of multiple disciplines such as ecology, chemistry, and physics, and it plays an important role in studying the balance of energy and chemical elements in ecological interactions (Elser et al., 2000; Sterner and Elser, 2002). In recent years, stoichiometric homeostasis and nutrient limitation have been widely studied in the context of ecological stoichiometry theory, and they are important parameters for reflecting the ecological strategy and adaptability of organisms to environmental changes (Jeyasingh et al., 2009; Persson et al., 2010). Previously, Yu et al. (2011) evaluated the stoichiometric homeostasis of vascular plants in Inner Mongolia grasslands. They found that factors influencing the stoichiometric homeostasis of plants included plant species, shape, development stage, and nutrient content; plants with a high degree of homeostasis were also more conservative in nutrient absorption. Moreover, studies have demonstrated that $\mathrm{N}$ application aggravates microbial phosphorus $(P)$ limitation, resulting in a decrease in the soil $N$ cycling potential in semi-arid areas (Cui et al., 2020). Although ecological stoichiometry plays a critical role in organically unifying the theories of different levels, from the molecular to ecosystem level (Elser et al., 2000; Sterner and Elser, 2002), studies on the response of terrestrial ecosystem components to environmental changes (e.g., $\mathrm{N}$ addition) remain limited.

Niche theory is another core concept in ecology, which has theoretical guidance for explaining interspecific relationships, species diversity and organism-environment interactions (Sterner and Elser, 2002). Niche has been extensively studied, but determining the number and type of niche dimensions has been challenging (Elser et al., 2010; Gonzalez et al., 2017; Atkinson et al., 2020). Since the acquisition, storage, and exchange of energy and material are essential for organisms, and the chemical composition of organisms also plays an important role in shaping its niche. Biochemistry, therefore, is likewise a key aspect of a species' niche (Elser et al., 2000; Sterner and Elser, 2002; Elser et al., 2010). Based on Niche theory, Gonzalez et al. (2017) proposed an approach to quantifying species' niche by visualizing the stoichiometric composition of individuals, and confirmed the applicability of this approach in terrestrial and freshwater communities composed by multiple trophic groups, which provides an effective way to assess and predict changes in community structure and species diversity due to species' niche differentiation and overlap (Gonzalez et al., 2017; Atkinson et al., 2020).

With the increase in fossil fuel and $\mathrm{N}$ fertilizer use, global atmospheric $\mathrm{N}$ deposition has significantly increased (Bergstrom and Jansson, 2006; Fang et al., 2011). The Loess Plateau, which exhibits serious soil erosion and poor soil quality, is an ecologically fragile region in China (Fu et al., 2011) and one of the ecosystems most vulnerable to the effects of $\mathrm{N}$ deposition. Many studies have extensively discussed the response characteristics of biomass, richness, diversity, and community structure of various components in the ecosystem after $\mathrm{N}$ application (LeBauer and Treseder, 2008; Wei et al., 2013; Wang et al., 2018; Zhang et al., 2019). However, in the above-mentioned changes of ecosystem components, it remains unclear what roles the dominant and companion species play, what roles the different functional group species (e.g., Gramineae, Compositae, and Leguminosae, etc.) play, and whether their respective plant-soilmicrobe systems respond consistently or differently to $N$ addition, all of which are critical to ecological restoration and management on the Loess Plateau. Therefore, we performed gradient $\mathrm{N}$ addition experiments with the dominant and companion species in different functional groups (a total of four typical herbaceous plants) in the Loess Plateau to explore the responses of different plant-soil-microbe systems. We hypothesized that (1) driven by $\mathrm{N}$ addition, the companion species and their rhizosphere microbes are more susceptible to P limitation; (2) excessive $\mathrm{N}$ application causes stoichiometric niche overlap among species; and (3) plant species of various functional groups have different or even opposite responses to $\mathrm{N}$ addition. 


\section{Material and methods}

\subsection{Site description}

This research was conducted at the Ansai Station of the Institute of Soil and Water Conservation, Chinese Academy of Sciences $\left(109^{\circ} 19^{\prime} \mathrm{E}, 36^{\circ} 51^{\prime} \mathrm{N}\right)$. The station is located in the hinterland of the Loess Plateau, which is a typical hilly loess and gully region, at an altitude of $1068-1309 \mathrm{~m}$ (Fig. 1). The region exhibits a temperate semi-arid climate, with an average annual temperature of $8.8^{\circ} \mathrm{C}$ and an average annual rainfall of $500 \mathrm{~mm}$. Precipitation primarily occurs between July and September every year (approximately $70 \%$ of the annual precipitation). The regional vegetation is that typical of a forest-grassland transitional zone, including Artemisia gmelinii (A. gmelinii), Bothriochloa ischemum (B. ischemum), Lespedeza davurica (L. davurica), Stipa bungeana ( $S$. bungeana), and Cleistogenes squarrosa (C. squarrosa), of which $B$. ischemum is the dominant species in the grassland community (Wu et al., 2014). The soil type is predominately loessal soil, which is characterized by a light soil color, looseness and softness, sufficient water permeability, and cultivability.

\subsection{Experimental design and sampling}

In July 2014, we investigated grassland communities with similar site conditions, and we selected and enclosed (to prevent grazing and human interference) an area of $30 \mathrm{~m} \times 30 \mathrm{~m}$ for the $\mathrm{N}$ addition experiment. The experiment consisted of a completely randomized design with four treatments and four replicates per treatment. There were 16 plots $(4 \times 4$ matrix $)$ with an area of $5 \mathrm{~m} \times 5 \mathrm{~m}$ each and a 1-m buffer zone between each of them. The four $\mathrm{N}$ treatment levels were $0 \mathrm{~g} \mathrm{~N} \mathrm{~m}^{-2} \mathrm{y}^{-1}$ (N0), $3 \mathrm{~g} \mathrm{~N} \mathrm{~m}^{-2} \mathrm{y}^{-1}$ (N3), $6 \mathrm{~g} \mathrm{~N} \mathrm{~m}^{-2} \mathrm{y}^{-1}$ (N6), and $9 \mathrm{~g} \mathrm{~N} \mathrm{~m}^{-2} \mathrm{y}^{-1}$ (N9). From 2015 to 2017, in April, June, August, and October, ammonium nitrate $\left(\mathrm{NH}_{4} \mathrm{NO}_{3}\right)$ was dissolved in $12.5 \mathrm{~L}$ of water, and the mixture was uniformly sprayed onto the plots using a backpack sprayer; the same volume of water was sprayed onto the N0 plot. The amount of $\mathrm{N}$ applied each time was a quarter of the total annual $\mathrm{N}$ application.

After three years of fertilization, plant and rhizosphere soil samples were collected in September 2017. Rhizosphere soil is the soil that remains firmly attached to the plant roots after excavating the plant-soil complex followed by lateral shaking (Garcia et al., 2005). In each plot, two sampling points with an area of $1 \mathrm{~m} \times 1 \mathrm{~m}$ (away from the plot edge) were randomly selected for vegetation investigation, and all plants and their rhizosphere soil samples in this area were collected. After digging out the plant roots, the rhizosphere soil attached to the roots was collected by species using a soft bristle brush, and it was filtered through a 2-mm screen mesh. The rhizosphere soil samples were immediately stored in a portable refrigerator and brought back to the laboratory where they were divided into subsamples. The first subsample was air-dried and sieved through $1-\mathrm{mm}$ and $0.25-\mathrm{mm}$ screen meshes to analyze its chemical properties. The second subsample was stored at $4^{\circ} \mathrm{C}$ to determine the microbial biomass and enzymatic activity. The plant tissue was sorted into shoots and roots through pruning, first dried for $30 \mathrm{~min}$ at $105^{\circ} \mathrm{C}$, then dried to a constant weight at $60^{\circ} \mathrm{C}$, and finally ground into a fine powder before sieving through a $0.25-\mathrm{mm}$ screen mesh to determine the plant chemical properties.

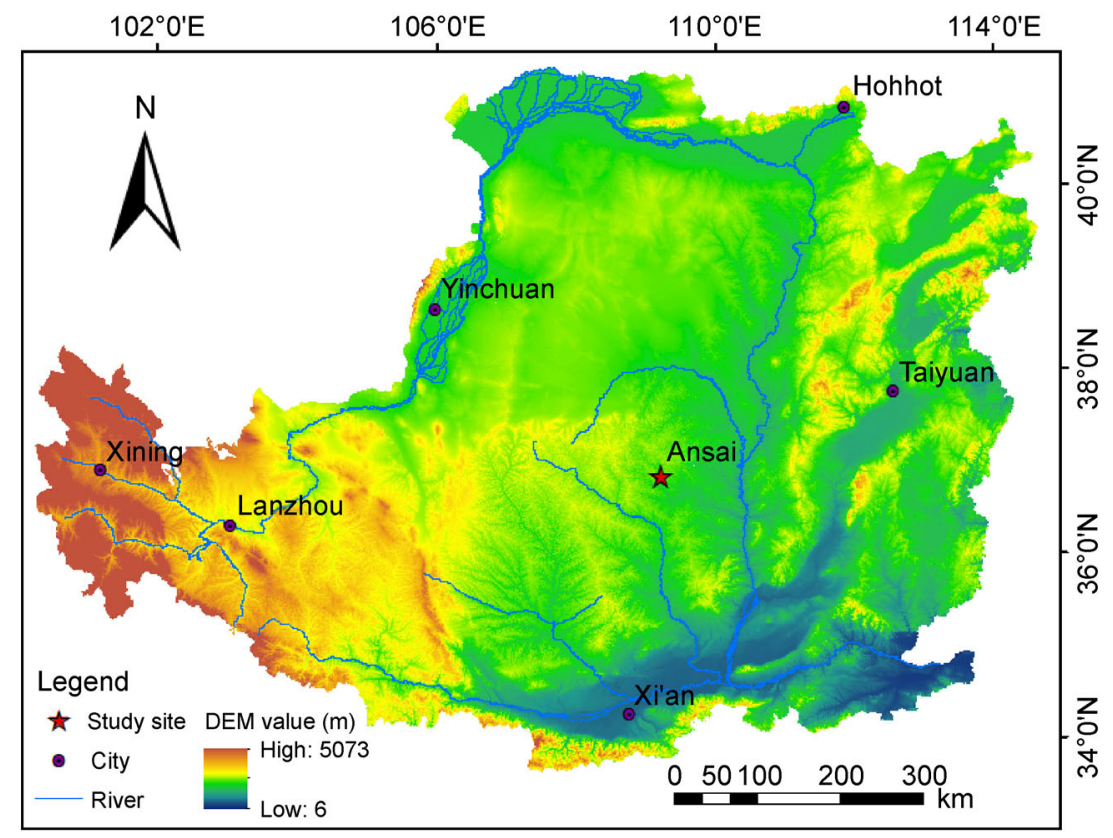

Fig. 1 Location of the study site (Ansai Station) on the Loess Plateau, China. DEM, digital elevation model. 


\subsection{Biogeochemical analyses}

The soil $\mathrm{pH}$ was determined for a 1:2.5 soil-water mixture using a glass electrode $\mathrm{pH}$ meter. Organic carbon $(\mathrm{C})$ content in plant tissues was determined using the $\mathrm{H}_{2} \mathrm{SO}_{4}-\mathrm{K}_{2} \mathrm{Cr}_{2} \mathrm{O}_{7}$ oxidation method. Dissolved organic carbon (DOC) contents were extracted with the deionized water after shaking for $1 \mathrm{~h}$, filtered through a $0.45-\mu \mathrm{m}$ Millipore filter (Jones and Willett, 2006), and then measured using a total organic carbon (TOC) analyzer (Liqui TOC II, Elementar, Germany). Total N content in plant tissues was measured using the Kjeldahl method (Bremner and Mulvaney, 1982). Soil ammonium $\mathrm{N}\left(\mathrm{NH}_{4}{ }^{+}-\mathrm{N}\right)$ and nitrate $\mathrm{N}\left(\mathrm{NO}_{3}{ }^{-}-\mathrm{N}\right)$ were determined using a continuous flow analyzer after extraction with $2 \mathrm{M} \mathrm{KCl}$ solution. We combined soil $\mathrm{NH}_{4}{ }^{+}-\mathrm{N}$ and $\mathrm{NO}_{3}{ }^{-}-\mathrm{N}$ to represent soil available $\mathrm{N}$ (AN) pools. The total $\mathrm{P}$ content in plant tissues was determined using the molybdenum-antimony anti-colorimetric method. Soil available $P(A P)$ content was extracted using sodium bicarbonate $\left(\mathrm{NaHCO}_{3}\right)$ solution and then determined using ultraviolet spectrophotometry (Olsen et al., 1982). Microbial biomass $\mathrm{C}, \mathrm{N}$, and $\mathrm{P}$ (MBC, MBN, and MBP, respectively) concentrations were measured using the chloroform fumigation-extraction method (Brookes et al., 1985; Vance et al., 1987).

We measured the potential activities of five soil enzymes based on standard fluorometric techniques described by Saiya-Cork et al. (2002) with modifications by German et al. (2011), including C-acquiring enzymes ( $\beta$-1,4-glucosidase (BG) and cellobiohydrolase $(\mathrm{CBH})), \mathrm{N}$-acquiring enzymes $(\beta-1,4-N$-acetylglucosaminidase (NAG) and L-leucine aminopeptidase (LAP)), and a $P$-acquiring enzyme (alkaline phosphatase (ALP)). The experimental procedure was described in detail in previous study (Zhang et al., 2019; Chen et al., 2020). Moreover, soil enzyme activities were normalized by using soil organic carbon (SOC) to reduce the impact of soil organic matter, which was expressed as $\mathrm{nmol} \mathrm{h}{ }^{-1} \mathrm{~g} \mathrm{SOC}^{-1}$.

\subsection{Statistical analyses}

We used the regression equation $y=c x^{1 / H}$ to calculate the stoichiometric homeostasis index and evaluate the homeostatic relationship between plants or microbes and soil resources based on the method described by Makino et al. (2003), where $y$ is the stoichiometry ratio of plant tissue or microbe, $x$ is the stoichiometry ratio of soil resources, and $c$ is a regression constant. If the regression relationship was not significant or $1 / \mathrm{H} \leqslant 0$, the homeostasis level was defined as strictly homeostatic. Additionally, the homeostasis index values with significant regressions were classified as homeostatic $(0<1 / \mathrm{H}<0.25)$, weakly homeostatic $(0.25<1 / \mathrm{H}<0.5)$, weakly plastic $(0.5<1 / \mathrm{H}<0.75)$, or plastic $(1 / \mathrm{H}>0.75)$ (Makino et al., 2003; Persson et al., 2010).

Resource limitations were explored by the enzymatic stoichiometry vector analysis. Vector length represents the C limitation, with a longer length indicating a greater $\mathrm{C}$ limitation; vector angle represents the $\mathrm{N}$ or $\mathrm{P}$ limitation, with an angle $<45^{\circ}$ indicating an $\mathrm{N}$ limitation and that $>45^{\circ}$ indicating a $P$ limitation. The calculation method was based on the equation proposed by Moorhead et al. (2016):

$$
\begin{gathered}
\text { Vector length }=\operatorname{SQRT}\left(x^{2}+y^{2}\right) \\
\text { Vector angle }=\operatorname{DEGREES}(\operatorname{ATAN} 2(x, y))
\end{gathered}
$$

where $x$ represents the relative activities of $\mathrm{C}$ - versus $\mathrm{P}$ acquiring enzymes (e.g., $(B G+C B H) /(B G+C B H+A L P))$, and $y$ represents the relative activities of $\mathrm{C}$ - versus $\mathrm{N}$ acquiring enzymes. The $N$ recovery efficiency $\left(R E_{N}\right)$ was calculated as the ratio of plant $\mathrm{N}$ accumulation to fertilizer application (Peng et al., 2006). The calculation used is as follows:

$$
\mathrm{RE}_{\mathrm{N}}(\%)=\left[\left(\mathrm{N}_{X}-\mathrm{N}_{0}\right) / \mathrm{F}\right] \times 100
$$

where $\mathrm{N}_{X}$ and $\mathrm{N}_{0}$ are the total $\mathrm{N}$ absorption of plant tissues (including shoots and roots) with and without $\mathrm{N}$ application, respectively, and the total $\mathrm{N}$ absorption is calculated by multiplying plant biomass by $\mathrm{N}$ content. $\mathrm{F}$ represents the total amount of $\mathrm{N}$ added.

Two-way analysis of variance (ANOVA) identified the effects of $\mathrm{N}$ addition on species and the resulting plant, rhizosphere soil, microbe, and enzyme stoichiometries using SPSS (version 24.0). Multiple comparisons were performed using Fisher least significant difference tests $(P<0.05)$. Changes in stoichiometric niches between plant species were evaluated using principal component analysis (PCA) in $R$ software (version 3.6.3) based on the theoretical ideas of Gonzalez et al. (2017) and Atkinson et al. (2020). The differences in these results were tested using permutational multivariate ANOVA (PERMANOVA). Variation partitioning analysis (VPA) showed that plant roots and soil nutrients have played a relatively important role in explaining changes in microbial biomass based on a redundancy analysis that utilized the "vegan" package in R software (version 3.6.3). Partial least squares path modeling (PLS-PM) was used to evaluate the direct and indirect effects of $\mathrm{N}$ addition on plant, rhizosphere soil, microbe, and enzyme stoichiometries. The model was constructed using the "innerplot" function from the "plspm" package in $\mathrm{R}$ software (version 3.6.3). Correlation heat maps were created using the "corrplot" package in $\mathrm{R}$ software (version 3.6.3).

\section{Results}

3.1 Stoichiometric homeostasis and nutrient limitations in plants and microbes

According to the stoichiometric homeostasis analyses (Table 1), all 1/H index values were less than zero or did not exhibit a significant relationship between the consumer (including plants and microbes) stoichiometry and that of rhizosphere soil resources, indicating that there was strict 
homeostasis in plant tissues and rhizosphere microbes. Although the shoot $N: P$ ratio of all plants increased significantly with the $\mathrm{N}$ addition gradients $(P<0.05)$, the N/P limitation was inconsistent across species (Fig. 2). For the dominant species ( $B$. ischemum), their shoot $\mathrm{N}: \mathrm{P}$ was $<14$ at low $\mathrm{N}$ concentration levels, indicating that there was an $\mathrm{N}$ limitation in plant shoots that was gradually relieved with increasing $\mathrm{N}$ levels (Han et al., 2005). In addition, the shoot $\mathrm{N}$ :P of $S$. bungeana was always $>16$, indicating a strong $P$ limitation (Han et al., 2005). With increasing $N$ levels, the shoots of the other two plant species changed from being weakly $\mathrm{N}$-limited (A. gmelinii) or co-limited by $\mathrm{N}$ and $\mathrm{P}(C$. squarrosa) to being $\mathrm{P}$-limited. In addition, the root $\mathrm{N}: \mathrm{P}$ ratio also increased significantly in all plants with increasing $\mathrm{N}$ levels $(P<0.05)$, but the increase proportion varied by species. The percentage increase of root N:P (from N0 to N9) was $30.13 \%$ (B. ischemum), $14.17 \%$ (S. bungeana), $24.06 \%$ (A. gmelinii), and $24.45 \%$ (C. squarrosa), respectively.

Vector analysis illustrated that the vector lengths were more responsive to $\mathrm{N}$ addition than the vector angles because the data clusters exhibited a wider distribution along the 1:1 diagonal (Fig. 3C). In addition, the vector lengths of all plant species significantly decreased at the N9 level, while the vector angles did not significantly change $(P<0.05$, Fig. 3A). All data points were above the 1:1 diagonal, and the vector angles were $>45^{\circ}$, which indicated a strong $P$ limitation for microbes in rhizosphere soil (Fig. 3B). The linear regression results displayed a significantly negative correlation between the vector length and angle $(P<0.001$, Fig. 3D).

3.2 Plant species stoichiometric niche characteristics at different $\mathrm{N}$ levels

PCA of plant nutrients and their stoichiometric ratios was performed to qualitatively evaluate changes in species stoichiometric niche characteristics under different $\mathrm{N}$ levels (Fig. 4). The differences in species results were assessed by PERMANOVA (Table S1). The results demonstrated that there were significant differences in plant nutrients and their stoichiometry ratios between species pairs (except those between $B$. ischemum and $C$. squarrosa) at the N0 and N3 levels $(P<0.05)$. However, these differences gradually disappeared with an increasing $\mathrm{N}$ application concentration, especially at the N6 level (Table S1).

\subsection{Variations in plant tissue $\mathrm{RE}_{\mathrm{N}}$ after $\mathrm{N}$ addition}

The $\mathrm{RE}_{\mathrm{N}}$ was calculated to characterize the effects of different $\mathrm{N}$ levels on various plant species (Fig. 5). The results illustrated that $\mathrm{RE}_{\mathrm{N}}$ of the dominant species (B. ischemum) significantly decreased with $\mathrm{N}$ addition gradients $(P<0.05)$, while there was no significant change in the companion species. In addition, the responses of plant species of different functional groups to $\mathrm{N}$ addition were inconsistent. For example, regardless of the $\mathrm{N}$ level, the Gramineae species (B. ischemum, S. bungeana, and $C$. squarrosa) $\mathrm{RE}_{\mathrm{N}}$ was $>0$, whereas the Compositae species (A. gmelinii) $\mathrm{RE}_{\mathrm{N}}$ was $<0$, which indicated that $\mathrm{N}$ addition negatively impacted the Compositae.

3.4 Variations in plant tissue nutrients and rhizosphere resources, and their effects on microbial biomass

The shoot and root $\mathrm{N}$ of all plant species both increased significantly with increasing $\mathrm{N}$ levels, yet they were significantly different at each $\mathrm{N}$ level $(P<0.05$, Fig. S1). Overall, the shoot and root $\mathrm{C}$ and $\mathrm{P}$ of various plants both displayed no apparent trends with increased $\mathrm{N}$ levels, and they differed significantly among the different species $(P<0.05$, Fig. S1). In
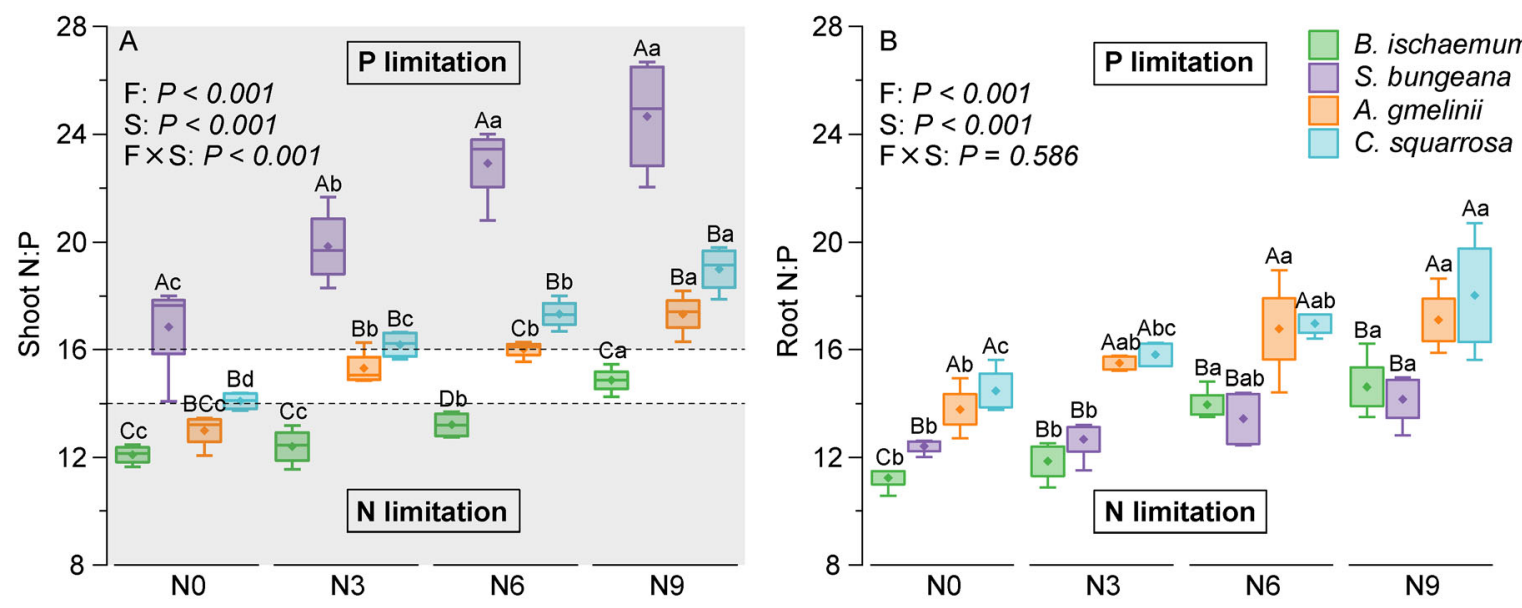

Fig. 2 Variations of N:P in shoots and roots of plants after $N$ addition. The dotted lines in (A) represent the thresholds (14 and 16$)$ for plant nutrient limitation. Results of two-way ANOVA are attached to the upper left corner of the figures. $F$, the main effects of fertilization; $S$, the main effects of species; $\mathrm{F} \times \mathrm{S}$, the interaction effects of fertilization and species. Different capital letters indicate significant differences among different species $(P<0.05)$, and different lowercase letters indicate significant differences among different $\mathrm{N}$ levels $(P<0.05)$. Values are means \pm standard error $(n=4)$. 
Table $11 / \mathrm{H}$ indexes and associated $R^{2}$ of describing the stoichiometric homeostasis in plants and microbes

\begin{tabular}{|c|c|c|c|c|c|c|c|c|c|}
\hline \multirow{2}{*}{ Resource (x) } & \multirow{2}{*}{ Consumer (y) } & \multicolumn{2}{|c|}{ B. ischaemum } & \multicolumn{2}{|c|}{ S. bungeana } & \multicolumn{2}{|c|}{ A. gmelinii } & \multicolumn{2}{|c|}{ C. squarrosa } \\
\hline & & $1 / H$ & $R^{2}$ & $1 / H$ & $R^{2}$ & $1 / \mathrm{H}$ & $R^{2}$ & $1 / H$ & $R^{2}$ \\
\hline & Shoot C:N & -0.17 & $0.77^{\star \star *}$ & -0.22 & $0.42^{* *}$ & -0.13 & 0.22 & -0.19 & 0.23 \\
\hline \multirow[t]{3}{*}{ DOC:AN } & Root C:N & -0.14 & $0.39^{* *}$ & -0.14 & $0.39^{* *}$ & -0.19 & 0.24 & -0.22 & $0.44^{* *}$ \\
\hline & MB C:N & 0.07 & 0.10 & 0.02 & $<0.01$ & -0.01 & $<0.01$ & -0.27 & 0.14 \\
\hline & Shoot C:P & -0.12 & $0.46^{\star *}$ & 0.02 & 0.01 & 0.02 & 0.02 & -0.03 & 0.13 \\
\hline \multirow[t]{3}{*}{ DOC:AP } & Root C:P & -0.08 & 0.13 & -0.10 & 0.22 & -0.08 & 0.05 & -0.11 & $0.41^{* *}$ \\
\hline & MB C:P & 0.24 & 0.15 & 0.27 & 0.19 & -0.02 & $<0.01$ & 0.19 & 0.13 \\
\hline & Shoot N:P & -0.23 & $0.51^{* \star}$ & -0.07 & 0.02 & -0.07 & 0.03 & -0.08 & 0.06 \\
\hline \multirow[t]{2}{*}{ AN:AP } & Root N:P & -0.29 & $0.42^{* \star}$ & -0.07 & 0.10 & 0.01 & $<0.01$ & -0.09 & 0.09 \\
\hline & MB N:P & 0.04 & $<0.01$ & -0.04 & $<0.01$ & 0.09 & 0.01 & 0.41 & 0.16 \\
\hline
\end{tabular}

$\mathrm{DOC}, \mathrm{AN}$, and AP represent soil dissolved organic carbon $(\mathrm{C})$, available nitrogen $(\mathrm{N})$, and available phosphorus $(\mathrm{P})$ contents in rhizosphere soil, respectively. Shoot $C, N$, and $P$ represent $C, N$, and $P$ contents in plant shoots, respectively. Root $C, N$, and $P$ represent $C, N$, and $P$ contents in plant roots, respectively. $\mathrm{MB} C, \mathrm{~N}$, and $\mathrm{P}$ represent microbial biomass $\mathrm{C}, \mathrm{N}$, and $\mathrm{P}$ contents. $1 / \mathrm{H} \leqslant 0$ by definition represents strictly homeostatic. ${ }^{*}, P<0.05,{ }^{* *}, P<0.01,{ }^{* *}, P<0.001$.

addition, $\mathrm{N}$ addition exerted substantial effects on DOC, AP, and $\mathrm{AN}(P<0.05$, Fig. S3). Moreover, the MBC and MBN in rhizosphere soil of various plants both first increased and then decreased significantly with increased $N$ levels $(P<0.05)$, while the MBP gradually decreased (Fig. S4). Similarly, N addition had significant effects on the activities of $\mathrm{C}-, \mathrm{N}-$, and $\mathrm{P}$-acquiring enzymes (represented as enzyme $\mathrm{C}, \mathrm{N}$, and $\mathrm{P}$, respectively) in rhizosphere soil $(P<0.05$, Fig. S5). With increased $\mathrm{N}$ levels, enzyme $\mathrm{C}$ first increased and then decreased regardless of plant species. Enzyme $\mathrm{N}$ of all plant species at the $\mathrm{N} 9$ level was higher than that at other $\mathrm{N}$ levels. In addition, enzyme $P$ of $B$. ischemum significantly decreased with increasing $N$ levels $(P<0.05)$, while that of other plant species did not significantly change. The results of VPA illustrated that, for the Gramineae, soil enzyme activity exhibited the highest rates of explained variations for microbial biomass, which were $67.0 \%, 52.1 \%$, and $71.6 \%$, respectively (Fig. 6A-D). However, for the Compositae, plant root nutrients exhibited the highest rate of explained variations for microbial biomass (43.4\%, Fig. 6C).

3.5 Effects of $\mathrm{N}$ addition on various plant-soil-microbe systems

Correlation analysis demonstrated that the relationships among plant tissue nutrients, rhizosphere soil nutrients, microbial biomass, and their stoichiometry of the dominant species ( $B$. ischemum) were closer than those of the companion species (Figs. S6 and S7). PLS-PM indicated that $\mathrm{N}$ addition significantly affected various plant-soilmicrobe systems (Figs. 7A-D), especially impacting plant (including shoot and root $\mathrm{C}, \mathrm{N}$, and $\mathrm{P}$ contents) and soil enzyme (including $\mathrm{C}-, \mathrm{N}$-, and $\mathrm{P}$-acquiring enzyme activities).
The effects of $\mathrm{N}$ addition on soil enzymes were negative for all systems $(P<0.05)$. However, as far as the plant was concerned, $\mathrm{N}$ addition produced direct positive effects on the Gramineae (total effects of 0.94, 0.95, and 0.91) but direct negative effects on the Compositae (total effects of -0.92 ) $(P<0.05$, Fig. 7E).

\section{Discussion}

4.1 Characteristics of stoichiometric homeostasis in plants and rhizosphere microbes

The stoichiometric homeostasis index was used to measure the homeostasis relationship between organisms and resources (Jeyasingh et al., 2009; Persson et al., 2010) to reflect organism adaptability to environmental changes (Elser et al., 2010). Previous studies on stoichiometric homeostasis have indicated that heterotrophs that need to draw nutrients from the external environment often exhibit stricter homeostasis, while the stoichiometric homeostasis of autotrophs is more flexible (Sterner and Elser, 2002). However, it was found that plants, similar to soil microbes, showed strict stoichiometric homeostasis in our study (Table 1), which was supported by the results of Yu et al. (2010). According to the "best configuration" principle in ecological economics (Allison et al., 2011), soil microbes tend to secrete corresponding C-, $\mathrm{N}$-, or P-acquiring enzymes depending on their relative nutritional requirements, so as to focus more targets on those resources that are most needed (Sinsabaugh and Moorhead, 1994; Peng and Wang, 2016). This is an important factor in microbes maintaining their stoichiometric homeostasis. Similarly, although plants appeared to have fewer means to maintain their homeostasis than did microbes 

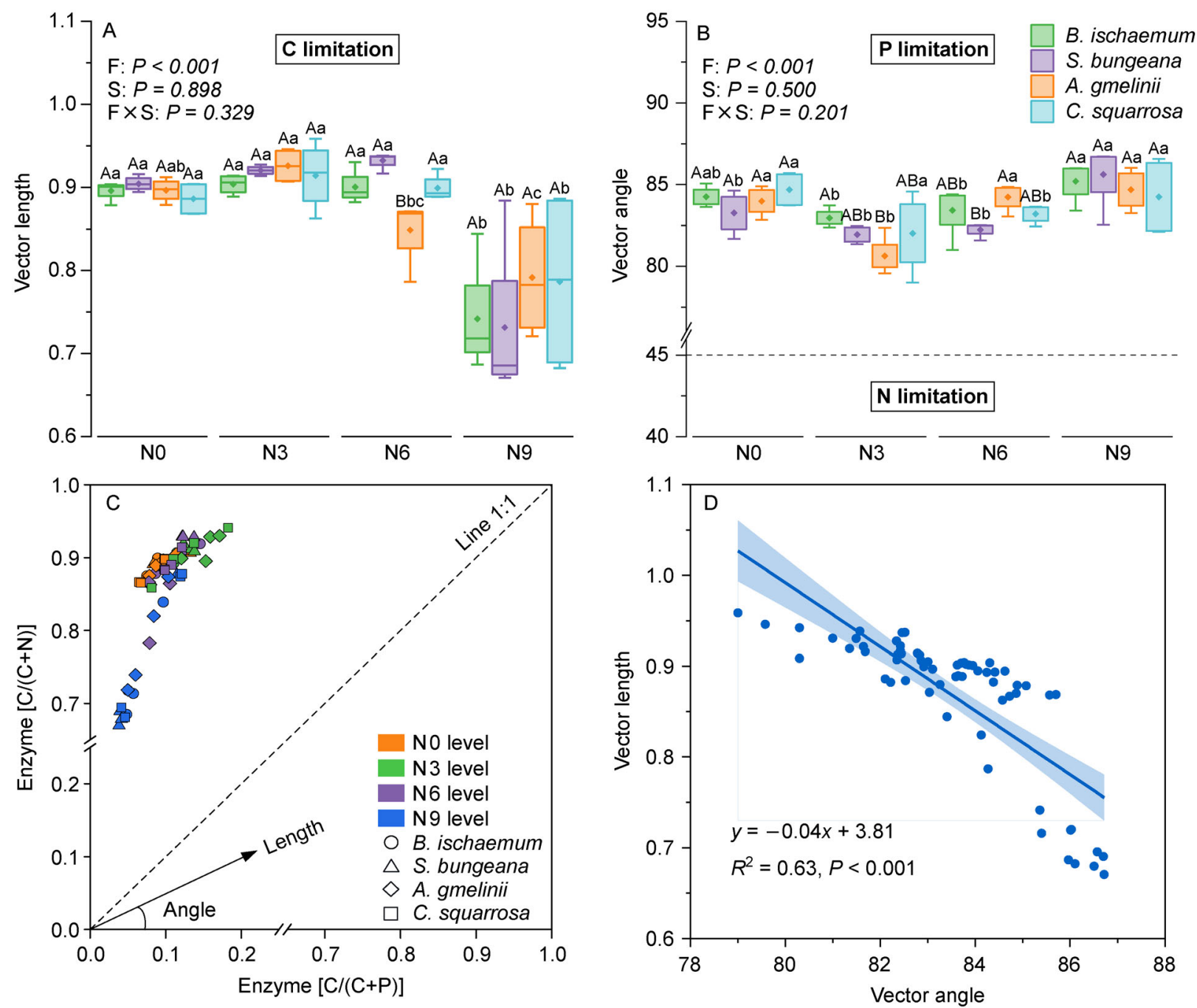

Fig. 3 Variations of vector length and angle ( $\mathrm{A}$ and $\mathrm{B}$ ) after $\mathrm{N}$ addition, ecoenzyme stoichiometry of the relative proportions of $\mathrm{C}$ to $\mathrm{N}$ acquisition versus $C$ to $P$ acquisition $(C)$ and their relationships ( $D$, grey areas represent the $95 \%$ confidence intervals). Enzyme $C$ (including $\beta-1,4-$ glucosidase and $\beta$-D-cellobiosidase) represents the activities of $C$-acquiring enzymes. Enzyme $N$ (including $\beta-1,4-N$-acetylglucosaminidase and L-leucine aminopeptidase) represents the activities of $\mathrm{N}$-acquiring enzymes. Enzyme $\mathrm{P}$ (alkaline phosphatase) represents the activities of $\mathrm{P}$-acquiring enzymes. (A and B): Results of two-way ANOVA are attached to the upper left corner of the figures. $F$, the main effects of fertilization; $S$, the main effects of species; $F \times S$, the interaction effects of fertilization and species. Different capital letters indicate significant differences among different species $(P<0.05)$, and different lowercase letters indicate significant differences among different $\mathrm{N}$ levels $(P<0.05)$. Values are means \pm standard error $(n=4)$.

(Sterner and Elser, 2002), the stoichiometry of all plants was also strictly homeostatic in this study.

Notably, the $\mathrm{N}$ contents in shoots and roots remarkably increased with increased $\mathrm{N}$ levels regardless of species $(P<0.05$, Fig. S1), which indicated that the absorption of $\mathrm{N}$ by plants continued to increase (Moreau et al., 2019). For a longterm environmental adaption, especially in environments with poor soil nutrients such as the Loess Plateau, the absorption and utilization of nutrients by plants are key to maintaining their biochemical stability (Gusewell, 2004). In addition, Yu et al. (2010) reported that the higher the stoichiometric homeostasis of plant species, the higher their dominance and stability. Moreover, they noted that the nutrient absorption strategies of plants with strictly stoichiometric homeostasis are more conservative. Indeed, as the dominant species in nutrient-poor environments, the $\mathrm{N}$ in the shoots and roots of $B$. ischemum was significantly lower than that of the other three companion species, regardless of the added $\mathrm{N}$ level (Fig. S1). This conservative nutrient absorption strategy may be more beneficial to the survival and reproduction of the dominant species (Yu et al., 2011).

4.2 Effects of $\mathrm{N}$ addition on nutrient limitation in plants and rhizosphere microbes

The N:P ratio in plant leaves is an important indicator to 

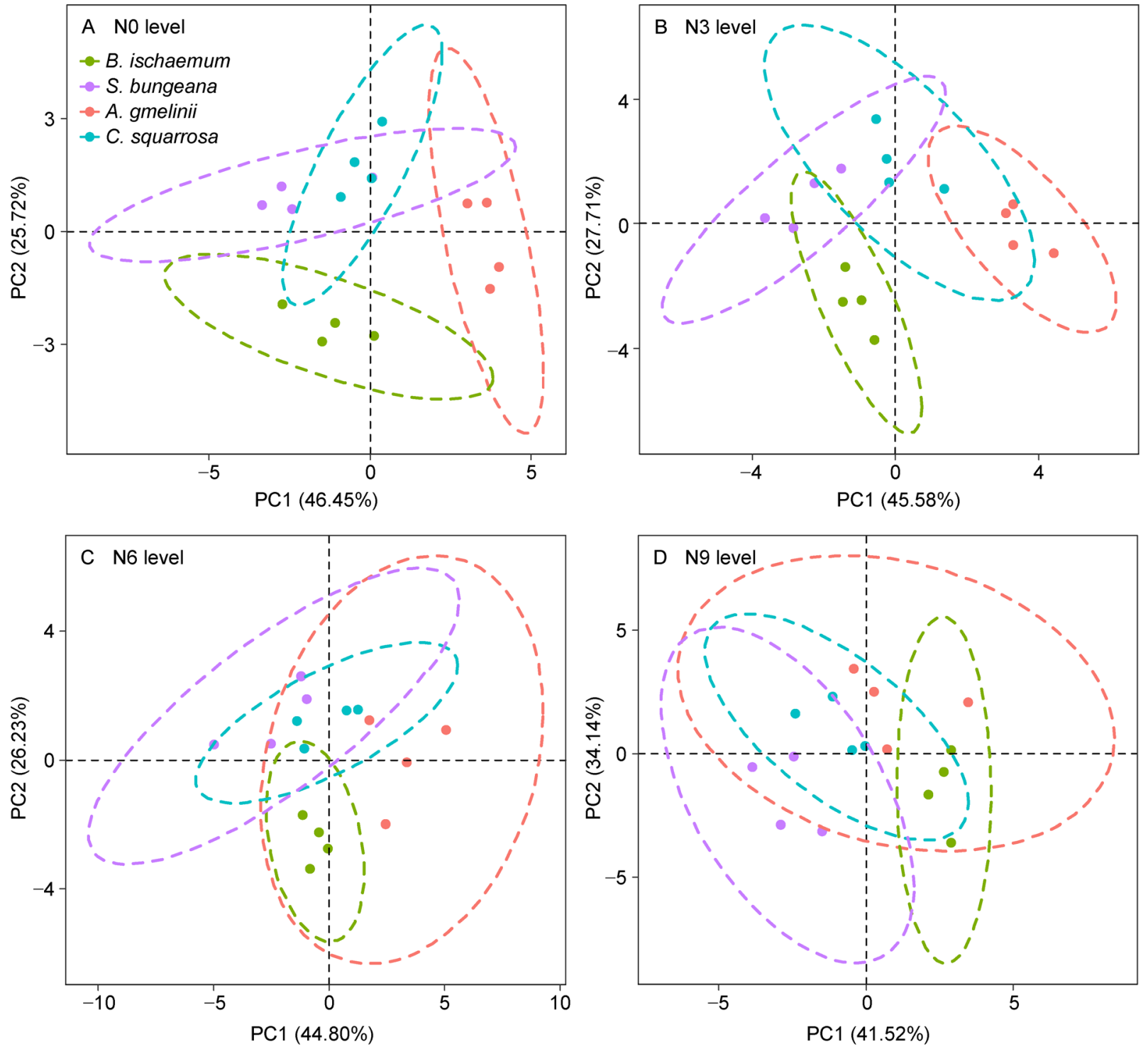

Fig. 4 Principal component analysis (PCA) of plant tissue stoichiometry (including shoot and root $C, N, P$, and their $C: N: P$ ratios) among different species at four N levels. (A), (B), (C), and (D) show PCA results of N0, N3, N6, and N9 level, respectively. The ellipses represent 95\% confidence intervals.

measure the $\mathrm{N}$ or $\mathrm{P}$ limitation (Han et al., 2005). Typically, the $\mathrm{N}: \mathrm{P}$ ratio $<14$ indicates a $\mathrm{N}$ limitation, and that $>16$ indicates a $\mathrm{P}$ limitation (Han et al., 2005). With the $\mathrm{N}$ addition gradients, the dominant species (B. ischemum) showed $\mathrm{N}$ limitation (shoot $\mathrm{N}: \mathrm{P}<14)$ or co-limitation of $\mathrm{N}$ and $\mathrm{P}(14<$ shoot $\mathrm{N}: \mathrm{P}<16)$, while the companion species $(A$. gmelinii and $C$. squarrosa) gradually shifted to $P$ limitation (shoot $N: P>16$ ), and $S$. bungeana was subject to a $P$ limitation that gradually strengthened (Fig. 2A). Although there is no clear threshold for nutrient limitation in roots, they showed a similar pattern of variation (Fig. 2B). These results indicated that the companion species were more susceptible to $P$ limitation than the dominant species, which partly supports our first hypothesis. As previously mentioned, the dominant species exhibited higher stoichiometric homeostasis and community stability
(Yu et al., 2010). The disadvantage of the companion species in this respect may be an important reason for their sensitivity to environmental changes such as $\mathrm{N}$ addition.

Interestingly, the root $\mathrm{N}: \mathrm{P}$ of $\mathrm{S}$. bungeana was generally low, indicating that its roots were mostly $\mathrm{N}$-limited, which was contrary to the $\mathrm{P}$ limitation in its shoots (Fig. 2). Previous studies have demonstrated different or even opposite strategies for nutrient investment and distribution in the shoots and roots of plants, which reflects the tradeoffs made by plants to adapt to environmental changes (Yu et al., 2010; Yu et al., 2011). Soil resources are the direct source of plant nutrients, and they play a vital role in plant growth and development (Wardle et al., 2004). Therefore, poor soil nutrients inevitably lead to a lack of plant nutrients (Gusewell, 2004). Compared with the results of previous studies (Cui 


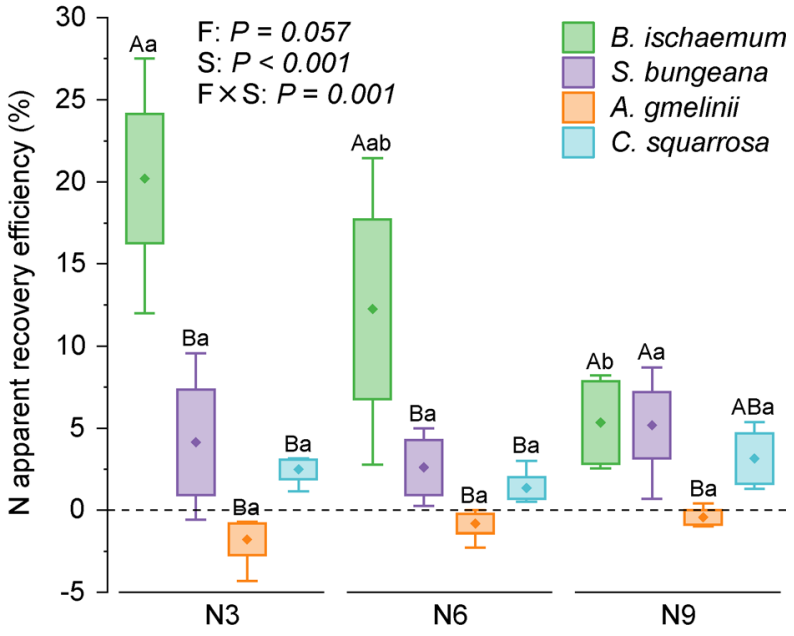

Fig. 5 Variations of $N$ apparent recovery efficiency $\left(R E_{N}\right)$ of plant tissues after $\mathrm{N}$ addition. Results of two-way ANOVA are attached to the upper left corner of the figures. F, the main effects of fertilization; $S$, the main effects of species; $F \times S$, the interaction effects of fertilization and species. Different capital letters indicate significant differences among different species $(P<0.05)$, and different lowercase letters indicate significant differences among different $\mathrm{N}$ levels $(P<0.05)$. Values are means \pm standard error $(n=4)$. et al., 2018; Han et al., 2019), lower soil AP content and a higher AN:AP ratio in this study may be the direct cause of plant P limitation (Han et al., 2005).

The vector analysis illustrated that the microbial $C$ limitation in the rhizosphere soil of all the studied plants was significantly alleviated at the N9 level (Fig. 3A). Furthermore, rhizosphere microbes experienced a strong $P$ limitation during the entire $\mathrm{N}$ application process regardless of plant species (Fig. 3B and 3C), which differed from the first research hypothesis. There was also a significant negative correlation between microbial $C$ and $P$ limitations $(P<0.001$, Fig. 3D). Previous studies have revealed that the soil microbial metabolism in arid and nutrient-poor ecosystems, such as the Loess Plateau, was primarily limited by N and P (TapiaTorres et al., 2015; Cui et al., 2019), which supports our results. Moreover, most of the nutrients required by microbes originated from the decomposition of soil organic matter (Ru et al., 2018); thus, the alleviation of a microbial nutrient ( $\mathrm{N}$ or $\mathrm{P}$ ) limitation also decreases the microbial acquisition of $\mathrm{C}$ (Marklein and Houlton, 2012). Therefore, the increase in soil available $\mathrm{N}$ caused by $\mathrm{N}$ addition reduced the difficulty for microbes to obtain $\mathrm{N}$ elements, thus reducing the degradation of organic matter by microbes, thereby presenting the relative alleviation of microbial $\mathrm{C}$ limitation. However, the reduction of soil organic matter decomposition further reduces the availability of soil $\mathrm{P}$, which can increase microbial $\mathrm{P}$ limitation (Marklein and Houlton, 2012; Ru et al., 2018).

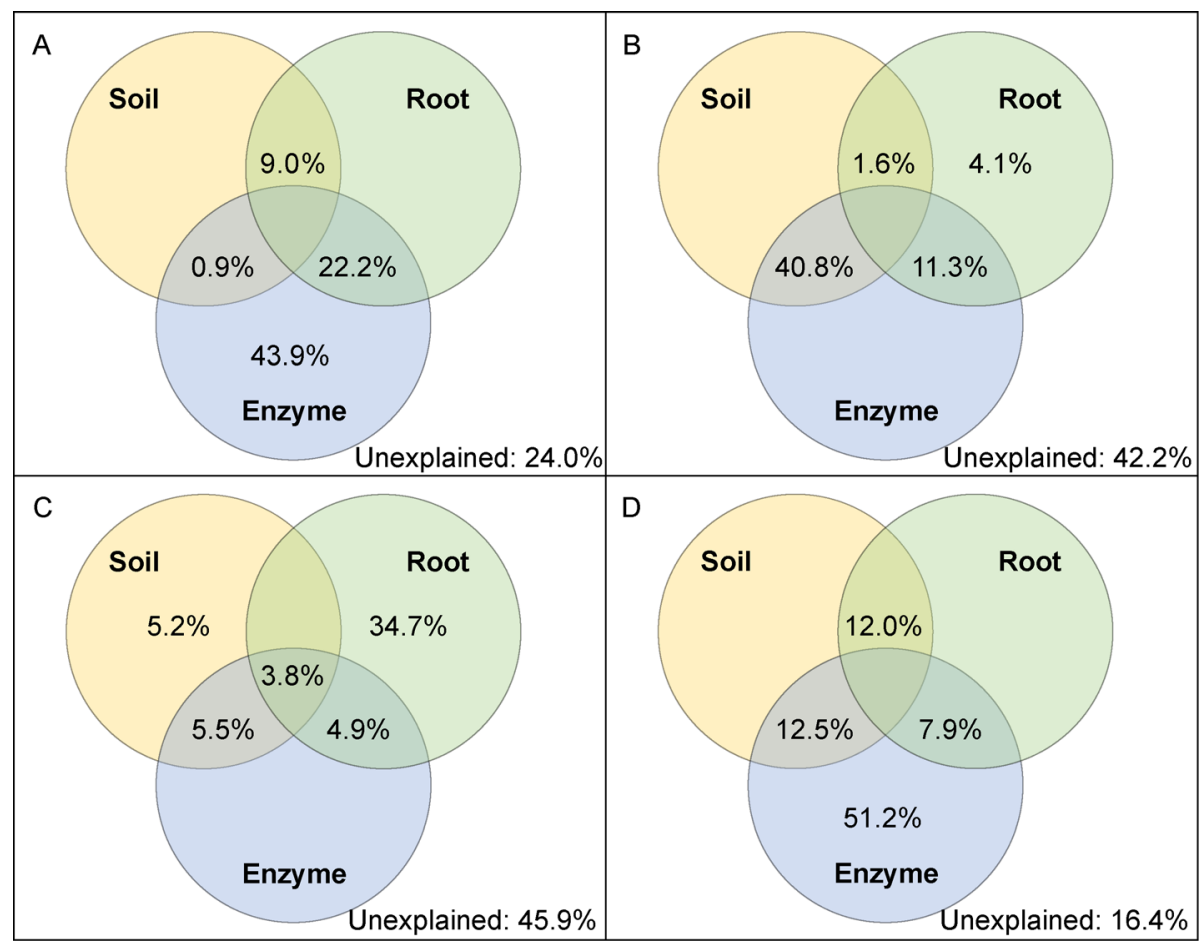

Fig. 6 Variation partitioning analysis (VPA) showing the explanations of soil nutrients, plant roots, and soil enzyme on variations in microbes (including microbial biomass $\mathrm{C}, \mathrm{N}$, and $\mathrm{P}$ ) after $\mathrm{N}$ addition. (A), (B), (C), and (D) show VPA results of $B$. ischaemum, $\mathrm{S}$. bungeana, $A$. gmelinii, and $C$. squarrosa, respectively. Soil represents rhizosphere soil nutrients, including dissolved organic carbon (DOC), available nitrogen (AN), and available phosphorus (AP). Root represents plant root nutrients, including root $\mathrm{C}, \mathrm{N}$, and P. Enzyme represents soil enzyme activities, including $\mathrm{C}$-, $\mathrm{N}$-, and $\mathrm{P}$-acquiring enzymes. 

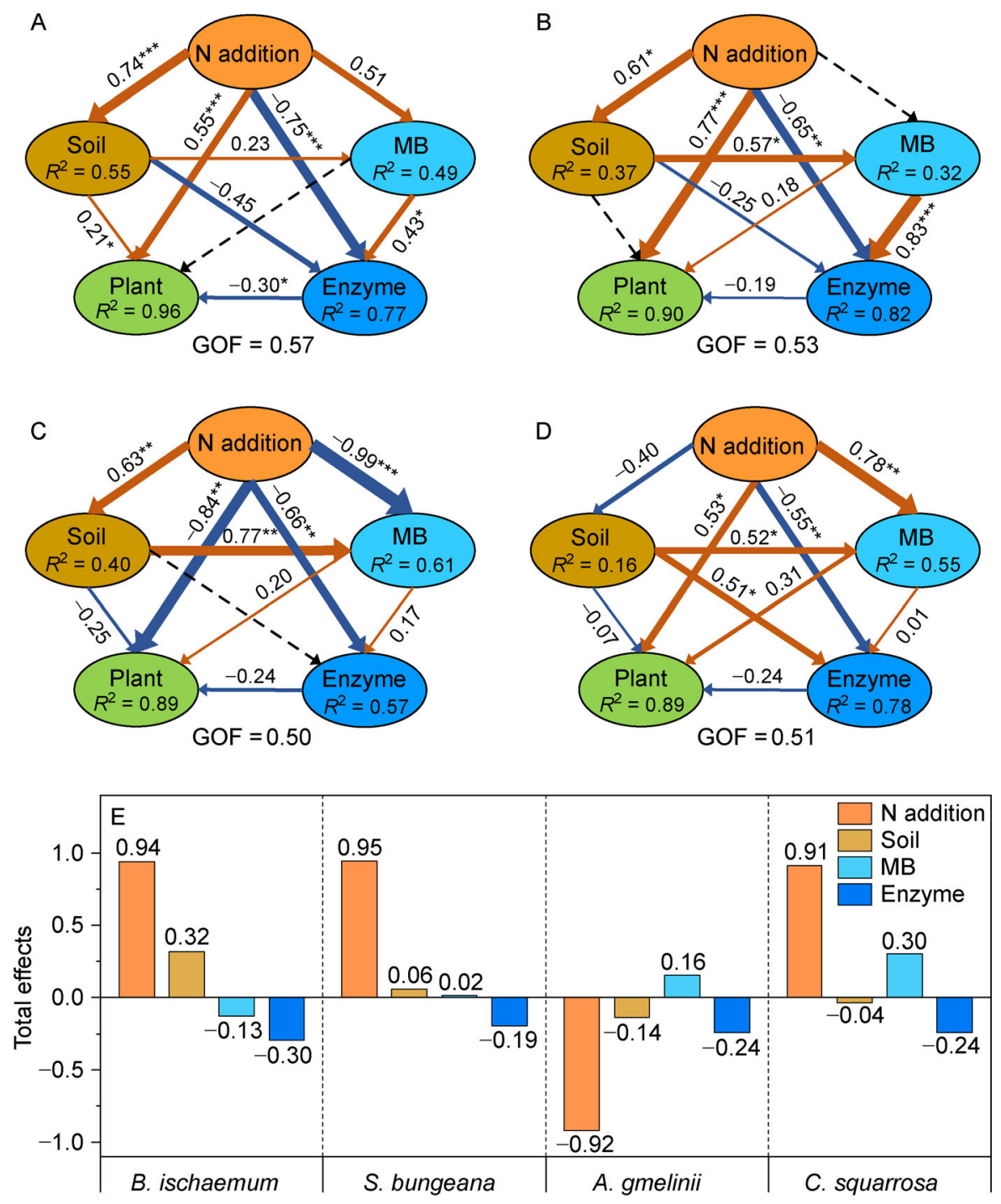

Fig. 7 Partial least squares path modelling (PLS-PM) showing the cascade relationships among rhizosphere soil nutrients, microbial biomass, soil enzyme activities, and plant nutrients under $\mathrm{N}$ addition. (A), (B), (C), and (D) show PLS-PM results of $B$. ischaemum, $S$. bungeana, A. gmelinii, and C. squarrosa, respectively. $(\mathrm{E})$ shows the total effects of $\mathrm{N}$ addition, Soil, MB, and Enzyme on Plant in each system. Orange and blue arrows indicate positive and negative flows of causality, respectively. The dotted black arrows represent nonsignificant path relationships removed to improve model fits. Numbers on the arrowed lines indicate normalized path coefficients. $R^{2}$ indicates the variance of the dependent variable explained by the model. Soil represents rhizosphere soil nutrients, including dissolved organic carbon (DOC), available nitrogen (AN), and available phosphorus (AP). MB represents microbial biomass, including microbial biomass $C, N$, and $P$. Enzyme represents soil enzyme activities, including $\mathrm{C}$-, $\mathrm{N}$-, and $\mathrm{P}$-acquiring enzymes. Plant represents nutrients in shoots and roots, including shoot and root $\mathrm{C}, \mathrm{N}$, and $\mathrm{P}$. GOF represents goodness of fit. ${ }^{*}, P<0.05,{ }^{* *}, P<0.01,{ }^{* *}, P<0.001$.

\subsection{Effects of $\mathrm{N}$ addition on plant species stoichiometric niches}

The niche concept is the basis of ecology, and it can be characterized by the phenotypic space occupied by species based on the premise of trait-based ecology (Gonzalez et al., 2017). Previous studies have revealed that the chemical components in organisms can shape their ecology, indicating that biochemistry is key to species niches (Sterner and Elser, 2002; Carnicer et al., 2015). Therefore, a new method was proposed based on ecological stoichiometry theory to describe niche, multidimensional stoichiometric niche. It was more conducive to quantitatively analyzing niche size and its driving factors (Gonzalez et al., 2017; Atkinson et al., 2020). This idea was applied and presented on a two-dimensional plane using PCA to qualitatively describe the differentiation or overlap of the stoichiometric niches in this research (Fig. 4). We found a significant differentiation in the stoichiometric niche among different species at the N0 and N3 levels, while more stoichiometric niche overlapping occurred at the $\mathrm{N} 6$ and N9 levels.

Simultaneously, these results were supported by PERMA- 
NOVA (Table S1), which indicated that excessive $\mathrm{N}$ addition aggravated the overlap of stoichiometric niches among species, especially those within the same functional group, which was in line with our second hypothesis. Many studies have demonstrated that communities with greater species or functional group diversity can utilize more available resources (e.g., water, nutrients, and light), thereby increasing their productivity and biomass through increased niche differentiation and reduced niche overlap (Cardinale et al., 2006; Cadotte, 2017; Lefcheck et al., 2015). Moreover, several studies (McKane et al., 2002; Xu et al., 2011) have also confirmed that plants can reduce competition for resources between species by using different forms of $\mathrm{N}$ (e.g., $\mathrm{NO}_{3}^{-}$, $\mathrm{NH}_{4}^{+}$, or free amino acids). Therefore, plant species compete symmetrically for limited resources by changing their nutrient absorption proportionally according to their niches (Cardinale et al., 2006; Ashton et al., 2010). However, in the present study, excessive $\mathrm{N}$ addition exacerbated the overlap of stoichiometric niches, thereby increasing competition and exclusion between species and seriously threatening species coexistence and diversity maintenance (Chesson, 2000).

\subsection{Responses of various plant-soil-microbe systems to $\mathrm{N}$ addition}

As an objective indicator to quantify the $\mathrm{N}$ recovery efficiency of plants after maturity, $\mathrm{RE}_{\mathrm{N}}$ can fully reflect how plant species respond to $\mathrm{N}$ addition treatment (Peng et al., 2006). In the current study, the $\mathrm{RE}_{\mathrm{N}}$ of the dominant species (B. ischemum) was remarkably higher than that of the companion species at the N3 and N6 levels (Fig. 5). The roots of B. ischemum are short rhizomes with strong tillering ability, and they are extremely developed, which may be an important reason why $B$. ischemum has superior $\mathrm{N}$ absorption and utilization compared to those of the companion species (Wang et al., 2017). However, the $\mathrm{RE}_{\mathrm{N}}$ of the dominant species ( $B$. ischemum) significantly decreased with increased $\mathrm{N}$ levels $(P<0.05$, Fig. 5), which may be due to the cytotoxic effect of a high $\mathrm{N}$ salt concentration inhibiting the absorption of nutrients through the plant roots (Enrique et al., 2008). More importantly, the $R E_{N}$ of Gramineae was always $>0$, while the $R E_{N}$ of Compositae (A. gmelinii) was always $<0$ and was significantly lower than that of the former, regardless of the $\mathrm{N}$ level $(P<0.05$, Fig. 5), which indicated that species in different functional groups showed opposite responses to $\mathrm{N}$ addition, supporting our third hypothesis.

We conducted PLS-PM to further investigate the responses of various plant-soil-microbe systems to $\mathrm{N}$ addition, and results similar to those of the $\mathrm{RE}_{\mathrm{N}}$ were obtained (Fig. 7). N addition exerted a significant positive effect on the Gramineae and a significant negative effect on the Compositae $(P<0.05$, Fig. 7E), which further confirmed our third hypothesis. On the one hand, these results may be related to the flowering phenology of plants. As a major limiting factor for plant growth in terrestrial ecosystems, an $\mathrm{N}$ increasing significantly affects the functional traits and reproductive strategies of plants
(Obeso, 2002; Niu et al., 2009). Plants face tradeoff between vegetative and reproductive growth, and the extension of one inevitably leads to the delay of the other (Bloom et al., 1985). Cleland et al. (2006) revealed that $\mathrm{N}$ addition significantly delayed the florescence of Gramineae, but advanced the florescence of forbs, indicating that Gramineae allocated more nutrients and time for growth rather than reproduction, whereas forbs did the opposite. Therefore, Gramineae with more growing periods need to absorb and convert more nutrients for their own growth, while Compositae may focus more on their reproduction. On the other hand, the growth rate and height of Gramineae were higher than those of nonGramineae after $\mathrm{N}$ application, putting Compositae at a disadvantage in the competition for resources (Li et al., 2011).

The interactions among plants, soil, and microbes greatly affect the material cycle process in terrestrial ecosystems (Wardle et al., 2004), especially in the rhizosphere, where the soil is the direct source of plant nutrient absorption and the carrier of microbial activities (DeForest et al., 2004; Caruso et al., 2005; Jian et al., 2016). Therefore, these relationships affect plant adaptation to environmental changes. For the Compositae, the VPA demonstrated that its roots displayed the greatest effect $(34.7 \%$ of variance explained) on rhizosphere microbes, and this effect was stronger than that of the Gramineae (Fig. 6), which indicated that there may be more fierce competition for nutrient between its roots and microbes (Kuzyakov and $\mathrm{Xu}, 2013$ ). This may also be an important reason for the inconsistent response of plant species to $\mathrm{N}$ addition across functional groups. Moreover, the relationship between the plant tissue and rhizosphere stoichiometry of the dominant species was closer than that of the companion species (Figs. S6 and S7), which indicated that its plant-soilmicrobe system had a faster nutrient cycling rate, allowing it to grow rapidly and occupy a dominant position (Wang et al., 2017). Similar to previous studies (Caruso et al., 2005; Chen et al., 2016b; Peng and Wang, 2016), there were also decoupling effects without a significant correlation in the plant-soil-microbe system that reflected the high degree of self-nutrient regulation by biological organisms with strict homeostasis (Gusewell, 2004).

\section{Conclusions}

In this study, although plant tissues appeared to exhibit fewer means to maintain their homeostasis than that of microbes, they both produced strict stoichiometric homeostasis during $\mathrm{N}$ addition. Moreover, there was a strong $P$ limitation in the rhizosphere microbial community regardless of plant species and $\mathrm{N}$ level, which was common in the Loess Plateau. However, compared with Gramineae, the roots of Compositae exhibited a higher explained variation rate on their rhizosphere microbes, indicating that there may be more intense competition for nutrient in their rhizosphere. In addition, the companion species were more susceptible to $\mathrm{P}$ limitation driven by $\mathrm{N}$ addition than the dominant species, and 
excessive $\mathrm{N}$ addition aggravated stoichiometric niche overlap among species, which intensified interspecific competitive exclusion. Overall, the effects of $\mathrm{N}$ addition on the dominant and companion species in different functional groups varied and were even the opposite in certain cases, providing a strong evidence for species composition and plant community diversity changes in $\mathrm{N}$-enriched environments. These results provides new insights into how plant-soil-microbe systems of different species in grassland communities respond to $\mathrm{N}$ addition.

\section{Acknowledgments}

This work was financially supported by Shaanxi Science Fund for Distinguished Young Scholars (2021JC-50), the National Natural Science Foundation of China (41771557), and Fundamental Research Funds for the Central Universities (2452021165). We would like to thank Editage (www.editage.cn) for English language editing.

\section{Conflicts of interest}

All the authors declare no conflicts of interest.

\section{References}

Allison, S.D., Weintraub, M.N., Gartner, T.B., Waldrop, M.P., 2011. Evolutionary-Economic Principles as Regulators of Soil Enzyme Production and Ecosystem Function, In: Shukla, G., Varma, A. (Eds.), Soil Enzymology. Springer-Verlag Berlin, Berlin, pp. 229 243.

Ashton, I.W., Miller, A.E., Bowman, W.D., Suding, K.N., 2010. Niche complementarity due to plasticity in resource use: plant partitioning of chemical $\mathrm{N}$ forms. Ecology 91, 3252-3260.

Atkinson, C.L., van Ee, B.C., Pfeiffer, J.M., 2020. Evolutionary history drives aspects of stoichiometric niche variation and functional effects within a guild. Ecology 101, e03100

Bergstrom, A.K., Jansson, M., 2006. Atmospheric nitrogen deposition has caused nitrogen enrichment and eutrophication of lakes in the northern hemisphere. Global Change Biology 12, 635-643 .

Bloom, A.J., Chapin, F.S. III, Mooney, H.A., 1985. Resource limitation in plants-An economic analogy. Annual Review of Ecology and Systematics 16, 363-392.

Bremner, J., Mulvaney, C., 1982. Nitrogen Total. Methods of Soil Analysis. Part 2. Chemical and Microbiological Properties. Soil Sci. Soc. Am. Inc Publisher, Madison, Wisconsin, USA.

Brookes, P.C., Landman, A., Pruden, G., Jenkinson, D.S., 1985. Chloroform fumigation and the release of soil nitrogen: $A$ rapid direct extraction method to measure microbial biomass nitrogen in soil. Soil Biology \& Biochemistry 17, 837-842.

Cadotte, M.W., 2017. Functional traits explain ecosystem function through opposing mechanisms. Ecology Letters 20, 989-996.

Cardinale, B.J., Srivastava, D.S., Duffy, J.E., Wright, J.P., Downing, A. L., Sankaran, M., Jouseau, C., 2006. Effects of biodiversity on the functioning of trophic groups and ecosystems. Nature 443, 989
992.

Carnicer, J., Sardans, J., Stefanescu, C., Ubach, A., Bartrons, M., Asensio, D., Penuelas, J., 2015. Global biodiversity, stoichiometry and ecosystem function responses to human-induced C-N-P imbalances. Journal of Plant Physiology 172, 82-91.

Caruso, G., Monticelli, L., Azzaro, F., Azzaro, M., Decembrini, F., La Ferla, R., Leonardi, M., Zaccone, R., 2005. Dynamics of extracellular enzymatic activities in a shallow Mediterranean ecosystem (Tindari ponds, Sicily). Marine and Freshwater Research 56, 173-188.

Chen, W., Zhou, H., Wu, Y., Wang, J., Zhao, Z., Li, Y., Qiao, L., Chen, K., Liu, G., Xue, S., 2020. Direct and indirect influences of longterm fertilization on microbial carbon and nitrogen cycles in an alpine grassland. Soil Biology \& Biochemistry 149, 107922.

Chen, W.Q., Zhang, Y.J., Mai, X.H., Shen, Y., 2016a. Multiple mechanisms contributed to the reduced stability of Inner Mongolia grassland ecosystem following nitrogen enrichment. Plant and Soil 409, 283-296.

Chen, Z.Q., Chen, Z.B., Yan, X.Y., Bai, L.Y., 2016b. Stoichiometric mechanisms of Dicranopteris dichotoma growth and resistance to nutrient limitation in the Zhuxi watershed in the red soil hilly region of China. Plant and Soil 398, 367-379.

Chesson, P., 2000. Mechanisms of maintenance of species diversity. Annual Review of Ecology and Systematics 31, 343-366.

Cleland, E.E., Chiariello, N.R., Loarie, S.R., Mooney, H.A., Field, C.B., 2006. Diverse responses of phenology to global changes in a grassland ecosystem. Proceedings of the National Academy of Sciences of the United States of America 103, 13740-13744.

Cui, Y.X., Fang, L.C., Deng, L., Guo, X.B., Han, F., Ju, W.L., Wang, X., Chen, H.S., Tan, W.F., Zhang, X.C., 2019. Patterns of soil microbial nutrient limitations and their roles in the variation of soil organic carbon across a precipitation gradient in an arid and semi-arid region. Science of the Total Environment 658, 1440-1451.

Cui, Y.X., Fang, L.C., Guo, X.B., Wang, X., Zhang, Y.J., Li, P.F., Zhang, X.C., 2018. Ecoenzymatic stoichiometry and microbial nutrient limitation in rhizosphere soil in the arid area of the northern Loess Plateau, China. Soil Biology \& Biochemistry 116, 11-21.

Cui, Y.X., Zhang, Y.L., Duan, C.J., Wang, X., Zhang, X.C., Ju, W.L., Chen, H.S., Yue, S.C., Wang, Y.Q., Li, S.Q., Fang, L.C., 2020. Ecoenzymatic stoichiometry reveals microbial phosphorus limitation decreases the nitrogen cycling potential of soils in semi-arid agricultural ecosystems. Soil \& Tillage Research 197, 10.

DeForest, J.L., Zak, D.R., Pregitzer, K.S., Burton, A.J., 2004. Atmospheric nitrate deposition, microbial community composition, and enzyme activity in northern hardwood forests. Soil Science Society of America Journal 68, 132-138.

Elser, J.J., Fagan, W.F., Denno, R.F., Dobberfuhl, D.R., Folarin, A., Huberty, A., Interlandi, S., Kilham, S.S., McCauley, E., Schulz, K. L., Siemann, E.H., Sterner, R.W., 2000. Nutritional constraints in terrestrial and freshwater food webs. Nature 408, 578-580.

Elser, J.J., Fagan, W.F., Kerkhoff, A.J., Swenson, N.G., Enquist, B.J., 2010. Biological stoichiometry of plant production: metabolism, scaling and ecological response to global change. New Phytologist 186, 593-608.

Enrique, A.G., Bruno, C., Christopher, A., Virgile, C., Steven, C., 2008. Effects of nitrogen availability on microbial activities, densities and 
functional diversities involved in the degradation of a Mediterranean evergreen oak litter (Quercus ilex L.). Soil Biology \& Biochemistry 40, 1654-1661.

Fang, Y.T., Yoh, M., Koba, K., Zhu, W.X., Takebayashi, Y., Xiao, Y.H., Lei, C.Y., Mo, J.M., Zhang, W., Lu, X.K., 2011. Nitrogen deposition and forest nitrogen cycling along an urban-rural transect in southern China. Global Change Biology 17, 872-885.

Fu, B.J., Liu, Y., Lu, Y.H., He, C.S., Zeng, Y., Wu, B.F., 2011. Assessing the soil erosion control service of ecosystems change in the Loess Plateau of China. Ecological Complexity 8, 284-293.

Garcia, C., Roldan, A., Hernandez, T., 2005. Ability of different plant species to promote microbiological processes in semiarid soil. Geoderma 124, 193-202.

German, D.P., Weintraub, M.N., Grandy, A.S., Lauber, C.L., Rinkes, Z. L., Allison, S.D., 2011. Optimization of hydrolytic and oxidative enzyme methods for ecosystem studies. Soil Biology \& Biochemistry 43, 1387-1397.

Gonzalez, A.L., Dezerald, O., Marquet, P.A., Romero, G.Q., Srivastava, D.S., 2017. The Multidimensional Stoichiometric Niche. Frontiers in Ecology and Evolution 5, 17.

Gusewell, S., 2004. N: P ratios in terrestrial plants: variation and functional significance. New Phytologist 164, 243-266.

Han, W.X., Fang, J.Y., Guo, D.L., Zhang, Y., 2005. Leaf nitrogen and phosphorus stoichiometry across 753 terrestrial plant species in China. New Phytologist 168, 377-385.

Han, Y.H., Dong, S.K., Zhao, Z.Z., Sha, W., Li, S., Shen, H., Xiao, J.N., Zhang, J., Wu, X.Y., Jiang, X.M., Zhao, J.B., Liu, S.L., Dong, Q.M., Zhou, H.K., Jane, C.Y., 2019. Response of soil nutrients and stoichiometry to elevated nitrogen deposition in alpine grassland on the Qinghai-Tibetan Plateau. Geoderma 343, 263-268.

Hill, B.H., Elonen, C.M., Jicha, T.M., Kolka, R.K., Lehto, L.L.P., Sebestyen, S.D., Seifert-Monson, L.R., 2014. Ecoenzymatic stoichiometry and microbial processing of organic matter in northern bogs and fens reveals a common P-limitation between peatland types. Biogeochemistry 120, 203-224.

Jeyasingh, P.D., Weider, L.J., Sterner, R.W., 2009. Genetically-based trade-offs in response to stoichiometric food quality influence competition in a keystone aquatic herbivore. Ecology Letters 12, 1229-1237.

Jian, S.Y., Li, J.W., Chen, J., Wang, G.S., Mayes, M.A., Dzantor, K.E., Hui, D.F., Luo, Y.Q., 2016. Soil extracellular enzyme activities, soil carbon and nitrogen storage under nitrogen fertilization: A metaanalysis. Soil Biology \& Biochemistry 101, 32-43.

Jones, D.L., Willett, V.B., 2006. Experimental evaluation of methods to quantify dissolved organic nitrogen (DON) and dissolved organic carbon (DOC) in soil. Soil Biology \& Biochemistry 38, 991-999.

Kuzyakov, Y., Xu, X.L., 2013. Competition between roots and microorganisms for nitrogen: mechanisms and ecological relevance. New Phytologist 198, 656-669.

LeBauer, D.S., Treseder, K.K., 2008. Nitrogen limitation of net primary productivity in terrestrial ecosystems is globally distributed. Ecology 89, 371-379.

Lefcheck, J.S., Byrnes, J.E.K., Isbell, F., Gamfeldt, L., Griffin, J.N., Eisenhauer, N., Hensel, M.J.S., Hector, A., Cardinale, B.J., Duffy, J.E., 2015. Biodiversity enhances ecosystem multifunctionality across trophic levels and habitats. Nature Communications 6,
6936.

Li, W., Wen, S.J., Hu, W.X., Du, G.Z., 2011. Root-shoot competition interactions cause diversity loss after fertilization: a field experiment in an alpine meadow on the Tibetan Plateau. Journal of Plant Ecology 4, 138-146.

Makino, W., Cotner, J.B., Sterner, R.W., Elser, J.J., 2003. Are bacteria more like plants or animals? Growth rate and resource dependence of bacterial C: N: P stoichiometry. Functional Ecology 17, 121-130.

Mao, W., Felton, A.J., Zhang, T., 2017. Linking changes to intraspecific trait diversity to community functional diversity and biomass in response to snow and nitrogen addition within an Inner Mongolian Grassland. Frontiers in Plant Science 8, 10.

Marklein, A.R., Houlton, B.Z., 2012. Nitrogen inputs accelerate phosphorus cycling rates across a wide variety of terrestrial ecosystems. New Phytologist 193, 696-704.

McKane, R.B., Johnson, L.C., Shaver, G.R., Nadelhoffer, K.J., Rastetter, E.B., Fry, B., Giblin, A.E., Kielland, K., Kwiatkowski, B. L., Laundre, J.A., Murray, G., 2002. Resource-based niches provide a basis for plant species diversity and dominance in arctic tundra. Nature 415, 68-71.

Moorhead, D.L., Sinsabaugh, R.L., Hill, B.H., Weintraub, M.N., 2016. Vector analysis of ecoenzyme activities reveal constraints on coupled C, N and P dynamics. Soil Biology \& Biochemistry 93, 1-7.

Moreau, D., Bardgett, R.D., Finlay, R.D., Jones, D.L., Philippot, L., 2019. A plant perspective on nitrogen cycling in the rhizosphere. Functional Ecology 33, 540-552.

Niu, K.C., Choler, P., Zhao, B.B., Du, G.Z., 2009. The allometry of reproductive biomass in response to land use in Tibetan alpine grasslands. Functional Ecology 23, 274-283.

Obeso, J.R., 2002. The costs of reproduction in plants. New Phytologist 155, 321-348.

Olsen, S., Sommers, L., Page, A., 1982. Methods of Soil Analysis. Part 2. Chemical and Microbiological Properties of Phosphorus. ASA Monograph 9, 403-430.

Peng, S.B., Buresh, R.J., Huang, J.L., Yang, J.C., Zou, Y.B., Zhong, X. H., Wang, G.H., Zhang, F.S., 2006. Strategies for overcoming low agronomic nitrogen use efficiency in irrigated rice systems in China. Field Crops Research 96, 37-47.

Peng, X.Q., Wang, W., 2016. Stoichiometry of soil extracellular enzyme activity along a climatic transect in temperate grasslands of northern China. Soil Biology \& Biochemistry 98, 74-84.

Persson, J., Fink, P., Goto, A., Hood, J.M., Jonas, J., Kato, S., 2010. To be or not to be what you eat: regulation of stoichiometric homeostasis among autotrophs and heterotrophs. Oikos 119, 741-751.

Ru, J.Y., Zhou, Y.Q., Hui, D.F., Zheng, M.M., Wan, S.Q., 2018. Shifts of growing-season precipitation peaks decrease soil respiration in a semiarid grassland. Global Change Biology 24, 1001-1011.

Saiya-Cork, K.R., Sinsabaugh, R.L., Zak, D.R., 2002. The effects of long term nitrogen deposition on extracellular enzyme activity in an Acer saccharum forest soil. Soil Biology \& Biochemistry 34, 13091315.

Sinsabaugh, R.L., Moorhead, D.L., 1994. Resource allocation to extracellular enzyme production: A model for nitrogen and phosphorus control of litter decomposition. Soil Biology \& 
Biochemistry 26, 1305-1311.

Song, L., Ba, X.M., Liu, X.J., Zhang, F.S., 2012. Impact of nitrogen addition on plant community in a semi-arid temperate steppe in China. Journal of Arid Land 4, 3-10.

Sterner, R.W., Elser, J.J., 2002. Ecological stoichiometry: the biology of elements from molecules to the biosphere. Princeton University Press.

Tapia-Torres, Y., Elser, J.J., Souza, V., Garcia-Oliva, F., 2015. Ecoenzymatic stoichiometry at the extremes: How microbes cope in an ultra-oligotrophic desert soil. Soil Biology \& Biochemistry $87,34-42$.

Vance, E.D., Brookes, P.C., Jenkinson, D.S., 1987. An extraction method for measuring soil microbial biomass C. Soil Biology \& Biochemistry 19, 703-707.

Wang, C.T., Long, R.J., Wang, Q.L., Liu, W., Jing, Z.C., Zhang, L., 2010. Fertilization and litter effects on the functional group biomass, species diversity of plants, microbial biomass, and enzyme activity of two alpine meadow communities. Plant and Soil 331, 377-389.

Wang, G., Xue, S., Liu, F., Liu, G., 2017. Nitrogen addition increases the production and turnover of the lower-order roots but not of the higher-order roots of Bothriochloa ischaemum. Plant and Soil 415, 423-434.

Wang, H.Y., Wang, Z.W., Ding, R., Hou, S.L., Yang, G.J., Lu, X.T., Han, X.G., 2018. The impacts of nitrogen deposition on community $\mathrm{N}: \mathrm{P}$ stoichiometry do not depend on phosphorus availability in a temperate meadow steppe. Environmental Pollution 242, 82-89.

Wardle, D.A., Bardgett, R.D., Klironomos, J.N., Setala, H., van der Putten, W.H., Wall, D.H., 2004. Ecological linkages between aboveground and belowground biota. Science 304, 1629-1633.

Wei, C.Z., Yu, Q., Bai, E., Lu, X.T., Li, Q., Xia, J.Y., Kardol, P., Liang, W. J., Wang, Z.W., Han, X.G., 2013. Nitrogen deposition weakens plant-microbe interactions in grassland ecosystems. Global Change Biology 19, 3688-3697.

Wu, G.L., Zhang, Z.N., Wang, D., Shi, Z.H., Zhu, Y.J., 2014. Interactions of soil water content heterogeneity and species diversity patterns in semi-arid steppes on the Loess Plateau of China. Journal of Hydrology (Amsterdam) 519, 1362-1367.

Xu, X., Ouyang, H., Richter, A., Wanek, W., Cao, G., Kuzyakov, Y., 2011. Spatio-temporal variations determine plant-microbe competition for inorganic nitrogen in an alpine meadow. Journal of Ecology 99, 563-571.

Yu, Q., Chen, Q.S., Elser, J.J., He, N.P., Wu, H.H., Zhang, G.M., Wu, J.G., Bai, Y.F., Han, X.G., 2010. Linking stoichiometric homoeostasis with ecosystem structure, functioning and stability. Ecology Letters 13, 1390-1399.

Yu, Q.A., Elser, J.J., He, N.P., Wu, H.H., Chen, Q.S., Zhang, G.M., Han, X.G., 2011. Stoichiometric homeostasis of vascular plants in the Inner Mongolia grassland. Oecologia 166, 1-10.

Zhang, J., Ai, Z., Liang, C., Wang, G., Liu, G., Xue, S., 2019. How microbes cope with short-term $\mathrm{N}$ addition in a Pinus tabuliformis forest-ecological stoichiometry. Geoderma 337, 630-640. 